\title{
INVESTIGATION OF THE CHEMICAL COMPOSITION OF IVY (HEDERA HELIX L.) SPECIES GROWING IN ÇAYCUMA, TURKEY
}

\author{
YAZICI, $\mathrm{H}$. \\ Design Department, Interior Design Program, Zonguldak Bülent Ecevit University, Çaycuma \\ Vocational School, Çaycuma, Zonguldak 67900, Turkey \\ (e-mail: h_yazici@hotmail.com; phone: +90-372-643-6601; fax: +90-372-643-6604)
}

(Received 22 $2^{\text {nd }}$ May 2020; accepted $20^{\text {th }}$ Aug 2020)

\begin{abstract}
In this study, the extractive substances of Hedera helix L. (forest ivy) wood and bark, naturally found around Filyos Stream in the Çaycuma district of Zonguldak, were investigated, for both ground-creeping individuals and for those clinging to Oriental plane (Platanus orientalis L.). The samples taken from the wood and bark of the plants were compared. According to the results of wood hexane experiments, linoleic acid (26.98\%) was the most abundant in normal wood samples. In the same experiments on bark, while linoleic acid $(25.40 \%)$ was determined to have the highest content in normal H. helix, palmiteloic acid $(17.09 \%)$ was the most abundant compound in plants clinging to trees. In acetone:water $(95: 5, \mathrm{v}: \mathrm{v})$ extract experiments on wood, the penetrating ivy wood contained the greatest amount of $\alpha$-D-glucopyranoside (58.47\%). Based on acetone:water (95:5,v:v) experiments on bark samples, sucrose (35.94\%) had the highest content in normal bark.
\end{abstract}

Keywords: ivy, oriental plane, lipophilic extractives, hydrophilic extractives, fatty acids

\section{Introduction}

The morphology and anatomy of plants change with enviromental factors. The physiological events that enable the growth, reproduction, survival behaviors, metabolism, and geographical distribution of plants are significantly influenced by the physical, chemical, and biotic factors of the surrounding environment (Lambers et al., 2008).

Hedera helix L. (forest ivy), an evergreen and clinging plant belongs to the Araliaceae family. It is located in forests and bushes with its fast polyploid capacity Although, it has a fast height increment the diameter increase slowly (Mandade et al., 2010). It can climb up to $30 \mathrm{~m}$ high by adhering strongly on solid surfaces with the help of adventitious roots where its root diameter can reach $20 \mathrm{~cm}$ (Brendler et al., 2003; Horz and Reichling, 2003; Schnitzler and Heuze, 2006; Stavretovic, 2007). The plant's ability to adhere to surfaces depends on the secretion of an adhesive composing of 60$85 \mathrm{~nm}$ diameter spherical nanocomposite polysaccharide and nanoparticles (Xia et al., 2010; Burris et al., 2012).

The leaves of Hedera helix L. are used in medical treatments. The main compounds found in the leaves are $\alpha$-hederin and hedefracoside $C$ with strong antioxidant activity (Gülçin et al., 2004). These compounds belong to the saponin group. Saponins have steroid or triterpenoid structure, and are usually used in disease treatment (Küçükkurt and Fidan, 2008; Mingjun et al., 2008; Fazio et al., 2009; Yollu, 2015; Muşmula et al., 2017). Also, Hedera helix L. is used extensively in traditional medicine due to its analgesic and anti-inflammatory properties (Mandade et al., 2010; Uddin et al., 2011).

Because of its climbing properties, it is also used for landscaping in walls, fences.

In its natural habitat this plant covers the ground area and it is described as "normal ivy" in this study (Figure 1), also, it embraces many tree species. Oriental plane (Platanus orientalis L.) is one of the tree species embraced by ivy (Figure 2). 


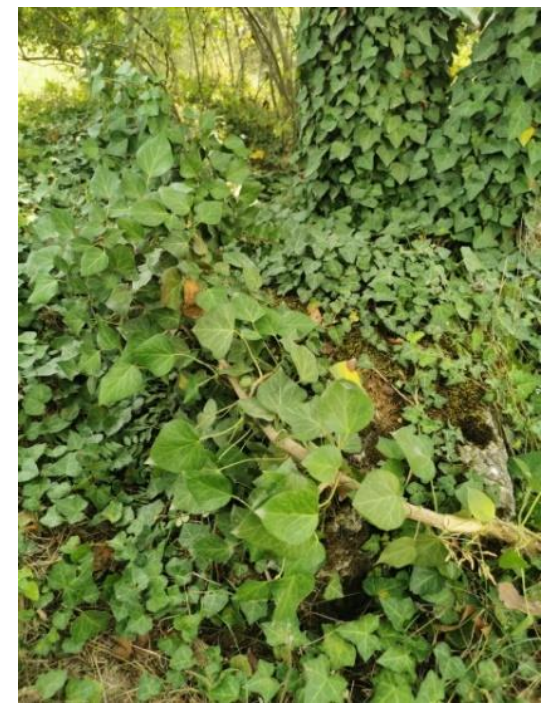

Figure 1. Normal ivy (Hedera helix L.) in its natural habitat

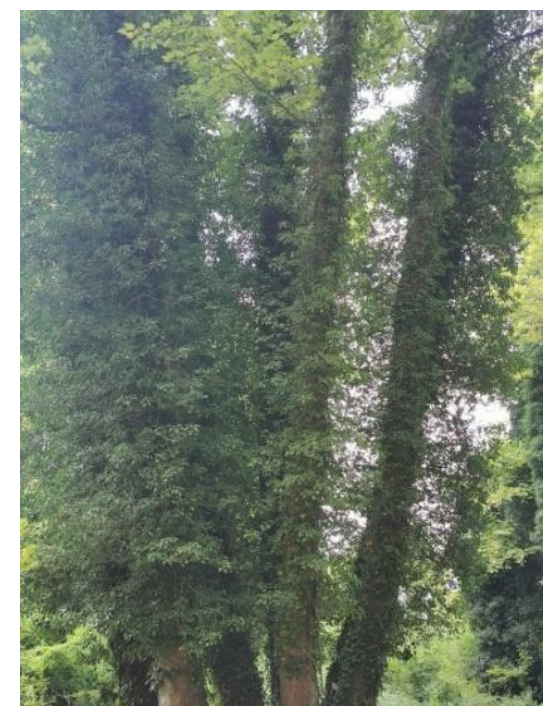

Figure 2. Penetrated ivy (Hedera helix L.) to Oriental plane (Platanus orientalis L.)

Oriental plane (Platanus orientalis L.), a member of the Platanaceae family and Platanus L. genus, can live up to 500-2000 years. Platanus orientalis L. natural distribution areas include Southern Europe and Southwest Asia, particularly the forests of Turkey and Iran (Davis, 1982; Anşin and Özkan, 2006; Zencirkiran and Erken, 2012). Naturally, they are typically found near the streams of forest and riversides; unnaturally, they are often used as ornamental plants and shade trees in cities and villages (Doğu, 2002).

In the chemical composition of the wood, the main components of the cell wall are polymer compounds, such as cellulose, hemicelluloses, and lignin. At the same time, the wood also contains extractives with lower molecular weights (Gindl and Teischinger, 2003; Papadopoulos, 2005; Dönmez and Dönmez, 2013). Most of the chemical groups found in wood are also seen in the bark with varying amounts. Generally, the content of 
the extractive substance in the bark is higher than that in the wood of the same tree (Sjöström et al., 1981). The extractives affect several properties of the tree, such as texture, odor, taste, and color. Extractives are lipophilic and hydrophilic substances that are soluble in neutral solvents (Fengel and Wegener, 1989; Sjöström, 1993; Holmbom, 1999). Lipophilic extractives, which are soluble in dichloromethane, ether and some hydrocarbon solvents, consist mostly of fats, fatty acids, resin acids and sterols. Comparatively, hydrophilic extractives are substances like carbohydrates, lignans, phenols, stilbens and chalkones that are soluble in polar solvents like water, alcohol and acetone (Holmbom, 1999). These chemicals are now being extracted for different industries, such as pharmaceutical, cosmetic, and food industry (Dönmez, 2018).

According to Yaman (2009), Hedera helix L.'s effect on the anatomical structure of Platanus orientalis L. is incidental. After a certain period of time on the tree, it was concluded that the invader cannot cause detrimental damage to the tree. In this context, compounds in the tree's wood support normal growth and both species can actually benefit (Hedera helix and Platanus orientalis). On the other hand, the literature regarding the chemical composition of $P$. orientalis on $H$. helix is out of our knowledge.

In this study, it was aimed to investigate chemical composition, especially extractive substances, of Hedera helix. Both normal and penetrating on Platanus oreintalis was analysed for the first time, thus, this work provides a novel source in literature.

\section{Materials and Methods}

\section{Materials}

Both normal grown ivy and the ivy penetrating to the oriental plane were used as study material. Both wood and bark samples were taken, with three replicates, from Filyos Stream in the Çaycuma district of Zonguldak in April 2019, where the altitude was $40 \mathrm{~m}$ $\left(41^{\circ} 22^{\prime} 56^{\prime \prime} \mathrm{N}, 32^{\circ} 5^{\prime} 13^{\prime \prime} \mathrm{E}\right)$. The sampling area can be seen in Figure 3. Cross-sections of the samples were prepared according to TAPPI standards. All samples were stored at $-24{ }^{\circ} \mathrm{C}$ until analyses. Wood was first debarked, and the bark was cut into small pieces. All samples were freeze-dried and ground by a Wiley mill into 1-mm (Ekman, 1983).
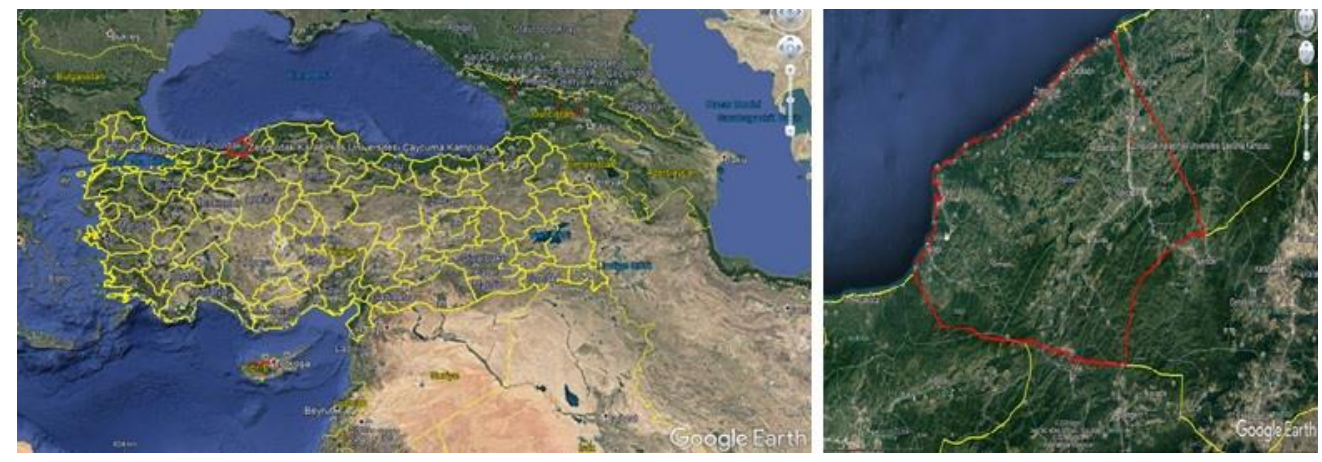

Figure 3. The sampling area

\section{Extraction}

Approximately $10 \mathrm{~g}$ of grounded wood and bark from each sample was successively extracted first with n-hexane and then with acetone:water (95:5, v:v) in a soxhlet. Samples were weighed before and after extraction to determine the extractive yield. 100 
$\mathrm{ml}$ aliquots of extractives were removed using rotary evaporator, followed by gravimetric analyses (Dönmez et al., 2016). For gravimetric analyses, $10 \mathrm{ml}$ aliquot was evaporated to dryness, i.e, constant weight, leaving a film of extractives in the solvent container. All results, given in $\mathrm{mg} / \mathrm{g}$, were calculated from freeze-dried samples. The appropriate amount of mixture was evaporated under nitrogen prior to silylation. The extracts obtained from hexane and acetone:water (95:5, v:v) were injected into GC-MS to identify the lipophilic and hydrophilic components.

\section{Chromatographic analyses of the extracts}

Chromatographic analysis of the extracts was carried out using a Shimadzu GC-2010 gas chromatograph equipped with an MS-QP 2010 mass spectrometer (Shimadzu Corporation, Kyoto, Japan). The instrument was equipped with a column, Rxi-5Sil MS $(30 \mathrm{~m} \times 0.25 \mathrm{~mm}$ i.d. $\times 0.25 \mu \mathrm{m}$ film thickness; Restek, Bellefonte, PA, USA); the temperature program was as follows, from $60{ }^{\circ} \mathrm{C}(1 \mathrm{~min})$ to $280{ }^{\circ} \mathrm{C}$ at $2{ }^{\circ} \mathrm{C} / \mathrm{min}$; injection temperature, $280{ }^{\circ} \mathrm{C}$; the carrier gas was $\mathrm{He}$ with a flow rate of $1 \mathrm{~mL} / \mathrm{min}$; the injection mode was split (10:1); the MS temperature was $280{ }^{\circ} \mathrm{C}$.

\section{Results and Discussion}

Wood and bark of the normal ivy and ivy penetrating to the oriental plane were analyzed by GC-MS to determine lipophilic and hydrophilic components after extraction with different solvents. In both normal and penetrated ivy wood, hexanesoluble extracts were found to be lower than acetone:water $(95: 5, \mathrm{v}: \mathrm{v})$ extracts. In comparison, the amount of hexane-soluble extracts in penetrated ivy wood was almost $50 \%$ higher than that in normal wood. Specifically, hexane extracts were determined to be $37.46 \mathrm{mg} / \mathrm{g}$ in penetrated ivy bark, $28.31 \mathrm{mg} / \mathrm{g}$ in normal, $3.22 \mathrm{mg} / \mathrm{g}$ in penetrated ivy wood, and $2.30 \mathrm{mg} / \mathrm{g}$ in normal wood. The amount of acetone:water-soluble extracts was found to be $31.31 \mathrm{mg} / \mathrm{g}$ in normal bark, $28.44 \mathrm{mg} / \mathrm{g}$ in penetrated ivy bark, 5.79 $\mathrm{mg} / \mathrm{g}$ in normal wood, and $6.32 \mathrm{mg} / \mathrm{g}$ in penetrated ivy wood. In hexane extracts, the increase of $40 \%$ in wood and $32 \%$ in bark samples of $H$. helix penetrating to the oriental plane tree were determined compared to normal $H$. helix. In addition, a 9\% increase in wood samples of $H$. helix penetrating to the oriental plane tree compared to normal grown wood, on the contrary, a $10 \%$ decrease in the penetrated wood compared to normal grown wood was observed in acetone-water extracts.

After isolating hexane-soluble extracts, the lipophilic components in wood and bark samples were obtained via a wiping process, then transmitted to vials and analyzed by GC-MS. The amounts of soluble substances were calculated gravimetrically and are shown in Table 1; lipophilic and hydrophilic components are displayed in Table 2 and Table 3, respectively.

Table 1. Gravimetric analysis of extracts from normal ivy and ivy penetrating to the oriental plane wood and bark ( $\mathrm{mg} / \mathrm{g}$ of dry weight)

\begin{tabular}{c|c|c|c}
\hline Sample Tree & Specimen & Hexane extract & Acetone:water extract \\
\hline \multirow{2}{*}{ Normal Hedera helix } & Wood & 2.30 & 5.79 \\
& Bark & 28.31 & 31.31 \\
\hline Hedera helix penetrated to & Wood & 3.22 & 6.32 \\
oriental plane & Bark & 37.46 & 28.44 \\
\hline
\end{tabular}


Table 2. The hexane-soluble extractive components determined by chromatographic analysis (\%)

\begin{tabular}{|c|c|c|c|c|}
\hline \multirow{2}{*}{ Name of Component } & \multicolumn{2}{|c|}{ Normal Hedera helix } & \multicolumn{2}{|c|}{$\begin{array}{c}\text { Penetrated Hedera helix to } \\
\text { oriental plane }\end{array}$} \\
\hline & Wood $(\%)$ & Bark (\%) & Wood $(\%)$ & Bark (\%) \\
\hline Palmitic Acid & 9.57 & 18.67 & 9.78 & 3.46 \\
\hline Propanoic Acid & 3.46 & 0.74 & 2.24 & 0.85 \\
\hline Stearic Acid & 3.47 & 3.14 & 2,07 & 4.65 \\
\hline Oleic Acid & 7.71 & 3.45 & 1.22 & 16.03 \\
\hline Linoleic Acid & 26.98 & 25.40 & 22.49 & 6.18 \\
\hline Linolenic Acid & - & - & 6.12 & 6.06 \\
\hline Miristic Acid & - & - & 6.42 & 3.78 \\
\hline Palmitoleic Acid & - & 12,26 & - & 17.09 \\
\hline Tetracosanoic Acid & 4.25 & 6.94 & - & 6.09 \\
\hline Dimethylmalonic Acid & - & - & 0,68 & - \\
\hline Octadecanol & - & - & 4.65 & 2.35 \\
\hline Hexadecanol & - & - & 2.49 & 3.15 \\
\hline Phtyol & - & 4.50 & - & - \\
\hline Ethanol & - & 5.55 & - & 0.76 \\
\hline Trans-Farnesol & - & 4.62 & - & 2.48 \\
\hline 2-Methylpentanol & - & - & 1.18 & 0.45 \\
\hline 2-Phenyl-1,2-propanediol & - & - & - & 0.57 \\
\hline Scyllo-Inositol & - & 1.77 & - & 1.58 \\
\hline Stigmasterol & 8.04 & 2.27 & 4.73 & 5.65 \\
\hline Stigmastenol & - & - & 2,10 & - \\
\hline Linalool & 1.00 & - & - & - \\
\hline Hexacosane & - & - & 5.03 & - \\
\hline Octacosane & - & - & 6.45 & 3.78 \\
\hline Eicosane & - & - & - & 2.89 \\
\hline Docosane & - & - & 3.69 & 1.23 \\
\hline Diethylacetamide & 9.39 & 2.32 & 6.09 & 2.58 \\
\hline N-Ethylacetamide & 18.08 & 4.54 & 11.73 & 5.17 \\
\hline Decanediamide & - & 2.29 & - & 0.52 \\
\hline Phosphoric Acid & 3.91 & - & 0.84 & 0.86 \\
\hline Oxalic Acid & - & 0.74 & - & - \\
\hline O-Menthone & 1.11 & - & - & - \\
\hline Succinate & - & 2.80 & - & 1,79 \\
\hline D-Threo-2,5-Hexodiulose & 3.03 & - & - & - \\
\hline
\end{tabular}

Wood and bark samples were taken from the same tree due to concepts of the value of environmental factors such as the area where plants are located in their growing areas. So, the extractive substances in normal ivy and in ivy penetrating to oriental plane, wood and bark were compared.

In hexane extracts, the highest component in normal and penetrating wood samples was linoleic acid $(26.98 \%, 22.49 \%$, respectively). Moreover, in bark samples, while linoleic acid $(25.40 \%)$ was determined as the highest in normal $H$. helix, palmiteloic acid $(17.09 \%)$ was the most abundant compound in penetrating tree. When observed in terms of components, the highest amount of the components in both normal and 
penetrating Hedera helix was the same while different components come to the fore in bark samples.

Table 3. The acetone: water-soluble extractive components determined by chromatographic analysis $(\%)$

\begin{tabular}{|c|c|c|c|c|}
\hline \multirow[t]{2}{*}{ Name of Component } & \multicolumn{2}{|c|}{ Normal Hedera helix } & \multicolumn{2}{|c|}{$\begin{array}{c}\text { Penetrating Hedera helix to } \\
\text { oriental plane }\end{array}$} \\
\hline & Wood $(\%)$ & Bark (\%) & Wood $(\%)$ & Bark (\%) \\
\hline Palmitic Acid & 1.17 & - & 0.51 & 1.09 \\
\hline Linoleic Acid & 1.94 & 1.32 & 1.87 & 6.22 \\
\hline Oleic Acid & - & 1.10 & - & 1.54 \\
\hline Glycerol & 3.33 & 1.68 & 3.09 & 2.30 \\
\hline Arabinitol & 7.51 & 1.50 & 0.72 & - \\
\hline Galactitol & 0.85 & 1.07 & - & - \\
\hline Myo-Inositol & - & - & 1.60 & - \\
\hline Erythritol & - & 2.04 & - & - \\
\hline D-Glucitol & - & - & - & 1.39 \\
\hline 2-Methyl-4-Keto-Pentan-2-Ol & - & 3.70 & 5.38 & - \\
\hline 2-Keto-D-Gluconic Acid & 0.61 & 2.03 & 1.96 & 1.50 \\
\hline$\alpha$-D-Gluco-pyranoside & - & - & 58.47 & - \\
\hline Arabinopyranose & - & 1.07 & - & - \\
\hline$\alpha$-D-Manno-pyranose & - & 6.58 & - & 4.18 \\
\hline$\beta$-D-Glucopyranose & - & - & - & 2.81 \\
\hline D-Fructose & 2.21 & - & 4.32 & 3.55 \\
\hline D-Turanose & - & 3.38 & - & 2.86 \\
\hline Maltose & - & - & - & 8.51 \\
\hline$\beta$-D-Glucose & 1.81 & - & 2.92 & - \\
\hline$\alpha$-D-Galactose & - & - & 0.51 & - \\
\hline D-Galactose & - & - & - & 0.73 \\
\hline Glucopyranose & 2.09 & - & 3.76 & 0.98 \\
\hline Sucrose & 47.10 & 35.94 & - & 43.15 \\
\hline Maltose & 0.91 & 5.11 & 3.68 & - \\
\hline Oxalic Acid & 0.85 & - & 0.74 & - \\
\hline Benzoic Acid & - & 5.39 & - & 0.75 \\
\hline$\beta$-Hydroquinone & 3.56 & 6.99 & 0.69 & 2.56 \\
\hline 6,7Dihydroxycoumarin & 6.74 & 12.74 & 0.86 & 7.94 \\
\hline Diethylacetamide & 2.91 & 1.65 & 2.57 & 1.54 \\
\hline Ethylacetamide & 5.68 & 3.15 & 5.08 & 3.00 \\
\hline Uridine & 6.02 & 3.56 & 1.25 & - \\
\hline Pentane & 4.71 & - & - & 3.40 \\
\hline
\end{tabular}

In the wood samples, acetone:water (95: 5, v: v) extract experiments to determine the structure and amount of hydrophilic components, sucrose $(47.10 \%)$ was determined as the highest in normal Hedera helix wood while $\alpha$-D-Glucopyranoside $(58.47 \%)$ was the dominant compound in penetrating wood. In addition, sucrose had the highest amount both in normal and penetrating bark of $\mathrm{H}$. helix, i.e. $35.94 \%, 43.15 \%$, respectively. 


\section{Conclusion}

Lipophilic and hydrophilic components of normally grown ivy and ivy penetrating to oriental plane tree in Turkey were obtained by extraction with hexane and acetone:water solvents. Analysis of the extractives were performed by GC-MS. Herein, the wood and bark of normal and penetrating ivy plants grown around Filyos Stream in the Çaycuma district of Zonguldak (Turkey) have been examined for the first time. It was determined that the amount of fatty acids in the bark of ivy is high. In order to evaluate this plant in industrial areas, more comprehensive studies should be done. On the other hand, this study provides a source for future research on the chemical analysis and influence of ivy penetration on plane tree wood and bark, providing a basis for the comparison and evaluation of similar conditions.

\section{REFERENCES}

[1] Anşin, R., Özkan, Z. C. (2006): Tohumlu Bitkiler [Spermatophytha]. Odunsu Taksonlar. - Karadeniz Teknik Üniversitesi, Orman Fakültesi 19: 450.

[2] Brendler, T., Grunwald, J., Janicke, C. (2003): Hedera helicis folium. - In: Herbal Remedies Electronic Database. Version 5, Medpharm Scientific Publishers, Stuttgart.

[3] Burris, J. H., Lenaghan, S. C., Zhang, M., Stewart, C. N. (2012): Nanoparticle biofabrication using English ivy (Hedera helix L.). - Journal of Nanobiotechnology 10(41): 1-9.

[4] Davis, P. H. (1982): Flora of Turkey and the East Aeagean Islands. - Edinburg at the University Press 7: 947.

[5] Doğu, A. D. (2002): Effective factors on wood structure. - Doğu Akdeniz Ormancılık Araştırma Müdürlüğ $u ̈$ 1: 81.

[6] Dönmez, Ş., Dönmez, İ. E. (2013): Structure and Benefits of Tree bark. - Süleyman Demirel Üniversitesi, Orman Fakültesi Dergisi 156-162.

[7] Dönmez, İ. E., Hemming, J., Willfor, S. (2016): Bark Extractives and Suberin Monomers from Arbutus andrachne and Platanus orientalis. - BioResources 11: 2809-2819.

[8] Dönmez, İ. E. (2018): Lipophilic and Hydrophilic Extractives from Strawberry Tree (Arbutus andrachne L.) and Oriental Plane (Platanus orientalis L.). - Wood Applied Ecology and Environmental Research 16: 741-747.

[9] Ekman, R. (1983): The suberin monomers and triterpenoids from the outer bark of Betula verrucosa Ehrh. - Holzforschung 37: 205-211.

[10] Fazio, S., Pouso, J., Dolinsky, D., Fernandez, A., Hernandez, M., Clavier, G., Hecker, M. (2009): Tolerance, safety and efficacy of Hedera helix extract in inflammatory bronchial diseases under clinical practice conditions: a prospective, open, multicentre postmarketing study in 9657 patients. - Phytomedicine 16(1): 17-24.

[11] Fengel, D., Wegener, G. (1989): Wood Chemistry. - Ultrastructure, Reactions, Walter de Gruyter, Berlin.

[12] Gindl, W., Teischinger, A., (2003): Comparison of the TL-shear strength of normal and compression wood of European larch. - Holzforschung 57: 421-426.

[13] Gülçin, I., Mshvildadze, V., Gepdiremen, A., Elias, R. (2004): Antioxidant activity of saponins isolated from ivy: alpha-hederin, hederasaponin-C, hederacolchiside-E and hederacolchiside-F. - Planta Medica 70(6): 561-563.

[14] Holmbom, B. (1999): Extractives. - In: Sjöström, E., Alén, R. (eds.) Analytical Methods in Wood Chemistry, Pulping, and Papermaking. Springer

[15] Horz, K. H., Reichling, J. (2003): Hedera. - In: HagerROM. Springer Verlag, Heidelberg.

[16] Küçükkurt, İ., Fidan, A. F. (2008): Saponinler ve Bazı Biyolojik Etkileri. - Kocatepe Veteriner Dergisi 1: 89-96. 
[17] Lambers, H., Chapin, F. S., Pons, T. L. (2008): Plant Physiological Ecology. - SpringerVerlag, New York.

[18] Mandade, R. J., Choudhuri, A., Mashirkar, V., Sakarkar, D. (2010): Analgesic and antiinflammatory activities of Hedera helix leaf extract. - International Journal of Comprehensive Pharmacy 1(4): 1-3.

[19] Mingjun, Z., Liu, M., Prest, H., Fisher, S. (2008): Nanoparticles Secreted from Ivy Rootlets for Surface Climbing. - Nano letters 8(5): 1277-1280.

[20] Muşmula, O. (2017): Extraction Optimization for the Preparation of Standardized Product from Hedera helix L. Plant and Development of Analysis Method with Ultra HPLCCAD]. - Msc. Thesis in Turkish, Ege University, İzmir, Turkey.

[21] Papadopoulos, A. N. (2005): An investigation of the cell wall ultrastructure of the sapwood of ten Greek wood species by means of chemical modification. - Holz als Rohund Werkstoff 63: 437-441.

[22] Schnitzler, A., Heuze, P. (2006): Ivy (Hedera helix L.) dynamics in riverine forests: effects of river regulation and forest disturbance. - Forest Ecology and Management 236: 12-17.

[23] Sjöström, E., Alén, R. (1981): Wood Chemistry: Fundamentals and applications. Academic Press, New York, pp. 169-189.

[24] Sjöström, E. (1993): Wood Chemistry: Fundamentals and Applications (2 ${ }^{\text {nd }}$ Edition). Academic Press, San Diego.

[25] Stavretovic, N. (2007): Biological characteristics of the species Hedera helix L. and its use in controllıng erosion in shady places. - Archives of Biological Sciences 59: 139-143.

[26] TAPPI T222 om-11. (2011): Acid-insoluble lignin in wood and pulp. - TAPPI Press, Atlanta, GA.

[27] Uddin, G., Rauf, A., Qaisar, M. N., Rehman, T. U., Latif, A., Ali, M. (2011): Preliminary phytochemical screening and antimicrobial activity of Hedera helix L. - Middle-East Journal of Science Research 8(1): 198-202.

[28] Xia, L., Lenaghan, S. C., Zhang, M., Wu, Y., Zhao, X., Burris, J. N., Stewart, N. C. (2010): Characterization of English ivy (Hedera helix) adhesion force and imaging using atomic force microscopy. - Journal of Nanoparticle Research 13(3): 1029-1037.

[29] Yaman, B. (2009): Comparative wood anatomy of ivy-hosting and non-hosting oriental plane (Platanus orientalis L.). - Plant Biosystems 143(2): 252-257.

[30] Yollu, Ç. F. (2015): Effect of treatment with Hedera helix folium extract (prospan ${ }^{\circledR}$ ) in the experimental arthritis model. - Msc. Thesis in Turkish, Trakya University, Edirne, Turkey.

[31] Zencirkiran, M., Erken, K. (2012): The effect of different times collecting cutting anfauxin treatments of the rooting in Platanus oriaentalis L. - The Journal of Animal \& Plant Sciences 22: 764-767. 